\title{
Population Change and Migration in Stavropol' Kray: The Effects of Regional Conflicts and Economic Restructuring
}

\author{
John O'Loughlin, Alexander Panin, and Frank Witmer' ${ }^{1}$
}

\begin{abstract}
The paper, by a joint American-Russian team of researchers, examines major changes in population composition and migration structure in Stavropol' Kray since the collapse of the Soviet Union. In addition to documenting increased rural- to urban-migration, the authors explore impacts on the kray of nearby conflicts in ethnic republics of the North Caucasus and in Transcaucasia, particularly the shift in ethnic composition of rural rayons in eastern Stavropol' (from Russian to non-Russian populations) and migration of Armenians and Russians to cities in western Stavropol'. Responses to a December 2005 survey (conducted by the authors) on past and possible future moves are presented together with an assessment of factors underlying the decision to move (mostly economic), as mediated by age, economic status, and gender. Also included is a detailed account of shifts in a typical rayon (Krasnogvardeyskiy - the birthplace of Mikhail Gorbachev) revealing trends that bode ill for service provision and a turnaround in negative population trends. Journal of Economic Literature, Classification Numbers: I30, J61, O15, O18. 4 figures, 2 tables, 35 references. Key words: Russia, Stavropol' Kray, migration intentions, Chechnya, Chechens, Dargins, Nogays, migration motivations, Armenians, North Caucasus, Russians.
\end{abstract}

\section{INTRODUCTION}

D ifferential ethnic mobility and patterns of settlement, in addition to the usual demographic factors of mortality, fertility, and migration, are increasingly important in influencing the nature of social and political development that is occurring in contemporary Russia. At a national level, there remains insufficient information about the multidimensional characteristics underlying these migration processes, thus hindering the effectiveness of regional policy. The years since the end of the Soviet Union have seen a growing

${ }^{1}$ Respectively, Professor of Geography, Institute of Behavioral Science, University of Colorado, Boulder, CO 80309-0487 (johno@colorado.edu); Assistant Professor, Institute of Geography, Stavropol' State University, Ulitsa Pushkina 1, Stavropol', 355009 Russia (alex_panin@mail.ru); and Research Assistant, Institute of Behavioral Science, University of Colorado, Boulder, CO 80309-0487 (witmer@colorado.edu). The authors would like to thank the National Science Foundation grant (no. 0433927) and the Committee for Exploration and Research of the National Geographic Society (John O'Loughlin, PI on both grants) for the financial support that made possible cooperative field work in the North Caucasus. Gearóid Ó Tuathail, Vladimir Kolossov, and Vitaliy Belozerov provided valuable assistance in designing the project, collecting information from disparate and scattered sources, and comradeship in the field. Ted Holland, especially, helped in post-field trip communications, whilst Nancy Thorwardson and Tom Dickinson of Computing and Research Services at the Institute of Behavioral Science, University of Colorado prepared the figures for publication with their exemplary skill, humor, and alacrity under pressure. The paper also benefited from the keen editorial eye of Nancy Thorwardson and the comments of Vladimir Kolossov. 
regional polarization in light of the rapid economic growth of global cities (Moscow, St. Petersburg) and specialized centers connected to the oil and gas industries that contrast with the peripheral and rural regions. Those republics characterized by complex ethnic compositions, as in the North Caucasus and proximate regions such as Stavropol' Kray (territory), have additional policy complications.

Stavropol' Kray occupies a special place in the strategy for Russia's territorial development because of its contemporary geopolitical position, at the center of the North Caucasus, contiguous to a majority of the republics of the area (see Figs. 1 and 2 in the preface to this special issue). Because it is a region with attractive urban and rural opportunities for employment in the immediate vicinity of zones of recent inter-ethnic conflict, it has become a primary destination for migrants. Stavropol' city and Kray have historically been known as an advance post of Russia in the Caucasus, ${ }^{2}$ with the kray mirroring numerous contemporary ethnic-demographic and migration problems of the North Caucasus region and, more generally, of the entire country. Over the period 1970-2006, migration processes in Stavropol' Kray have significantly changed in both scale and direction. Concomitantly, the ethnic structure of the kray's population has changed more dynamically than any of the other North Caucasian territories, which is clearly evident in the growing territorial differentiation and increase in the kray's population (Belozerov, 2005).

With a 2004 population of 2,726,000, Stavropol' Kray is the largest of the North Caucasus regions studied in this special issue, ${ }^{3}$ but more rapid population growth in Dagestan in recent years has probably now relegated Stavropol' to second place (Belozerov and Panin, 2003, 2006). Most of the territory is steppe-like with a marked trend toward drier grassland to the south and east. The rayons on the borders with Kalmykia and Dagestan are sparsely populated, with sheep-herding the major agricultural activity. To the northwest, large farms (formerly kolkhozy), dominate in the chernozem soils (Ryazantsev, 2003). ${ }^{4}$ Here, grains are the main product but the transition from the Soviet agricultural model has been difficult, marked by a declining rural population due to out-migration from rural communities. ${ }^{5}$ In the south of the region lies the piedmont, of which the southwestern part known as Kavkaz Mineral'nyye Vody (Caucasian Mineral Waters) is a region of spa and resort cities that developed during the early to mid-19th century. After severe dislocation of the organized Soviet vacation model in the early 1990s, the spas have regained nearly half of their former business, judging from the number of tourists (Radvanyi and Mudyuev, 2007, p. 171). Farther south are the ethnic republics (Karachayevo-Cherkessia, Kabardino-Balkaria, North Ossetia, Ingushetia, Chechnya, and Dagestan) that lie partly on the piedmont and partly in the high Caucasus Mountains that rise to the borders with Georgia and Azerbaijan.

In this paper, we present both aggregate and individual analyses of migration in Stavropol' Kray over the past 35 years. Cartographic analysis of detailed year-to-year migration statistics, supplemented by data from the Russian national censuses in 1970, 1979, 1989, and 2002 disaggregated by ethnicity, allows us to determine the main trends. Because of its location on the edge of the zone of geopolitical tension, Stavropol's population geography is directly affected by terrorist attacks on its cities, by the militarization of its landscape, by the forward basing of Russian federal police and military, and by periodic damage to key elements of its infrastructure (railroads, oil pipelines). We also include an aggregate account of

${ }^{2}$ See the introductory essay in this special issue (O'Loughlin et al., 2007).

${ }^{3}$ Krasnodar Kray at 5.1 million is the largest region in the Southern Federal District.

${ }^{4}$ See Figure 3 in the preface/map supplement of this special issue.

${ }^{5}$ This type of rural decline occurs throughout Russia (Ioffe and Nefedova, 2000, 2004). 
one of the territory's typical rayons, namely Krasnogvardeyskiy (literally, Red Guard). For the individual-level analysis, we conducted a survey of the residents of Stavropol' Kray as part of the large project on inter-ethnic attitudes and geopolitical preferences in the North Caucasus. Specifically, we asked questions about the nature of the local economy and the causes of the regional unrest from the respondents' perspective. We also queried the respondents about their recent migration history and future intentions to move. Answers to these questions were then examined using standard socio-demographic predictors (age, gender, education, ethnicity, etc.) and perceived economic prospects. ${ }^{6}$

\section{SETTLEMENT AND MIGRATION, 1970-2005}

The study of migration in Stavropol' Kray during the post-Soviet period must be placed within the context of geographic and economic processes affecting its population since 1970 . Data on rayon-level changes are available from successive Soviet censuses conducted in $1970,1979,1989$, as well as the first census of the Russian Federation in 2002. We also draw on previous research on the subject by local researchers. The 1970s were characterized by significant in-migration into the region, with almost 79 percent directed toward urban localities, a distinctive feature of the development of Soviet urbanization in previously less-urbanized regions, such as Stavropol' Kray. As might be expected, the city of Stavropol', as the administrative center as well as a leading industrial hub with cultural and educational facilities, attracted the largest stream of younger migrants arriving for study and new job opportunities. Nevinnomyssk in the southwest (Fig. 1) also was important as a destination for migrants due to new industrial growth (Masliyev, 2006).

The health-oriented resort cities of Kavkaz Mineral'nyye Vody offered numerous job opportunities for would-be migrants, although Soviet administrative regulations limited residential registration, thus artificially reducing in-migration. Smaller cities, with the exception of Budennovsk, were characterized by lower levels of in-migration than even the rural rayons, for which they serve as administrative centers. No cities in the kray recorded a population loss due to net out-migration during this period (Belozerov et al., 1993).

In rural areas, significant differences in migration were evident, with highest rates of out-migration occurring in rayons of northeastern (Apanasenkovskiy, Arzgirskiy), central (Petrovskiy), and northwestern Stavropol' Kray (Krasnogvardeyskiy). Population loss in these rayons was ameliorated due to the replacement of Russians by North Caucasian peoples. Additionally, active land reclamation in eastern Stavropol' Kray minimized the intensity of out-migration from this rural region, already showing signs of agricultural stress due to overuse of land resources.

During the $1980 \mathrm{~s}$, the overall number of in-migrants fell by 15.6 percent relative to the preceding decade, although the number gravitating to rural areas increased by 38 percent between 1979 and 1989, reflecting in large measure moves by people displaced by the 1988 earthquake in Armenia and by Nagorno-Karabakh-related new conflicts between Azerbaijan and Armenia (Ryazantsev, 1999; see also Rowland, 2007). Larger cities such as Stavropol' and Nevinnomyssk, and even the majority of small cities, also registered migration growth.

By the late 1980s, and especially in the 1990s, in-migration into the kray was driven increasingly by forced movement from the ethnic republics of the Russian Federation to the

${ }^{6}$ Details concerning the questionnaire and survey design/sampling are presented in O’Loughlin and Ó Tuathail, (2006). 


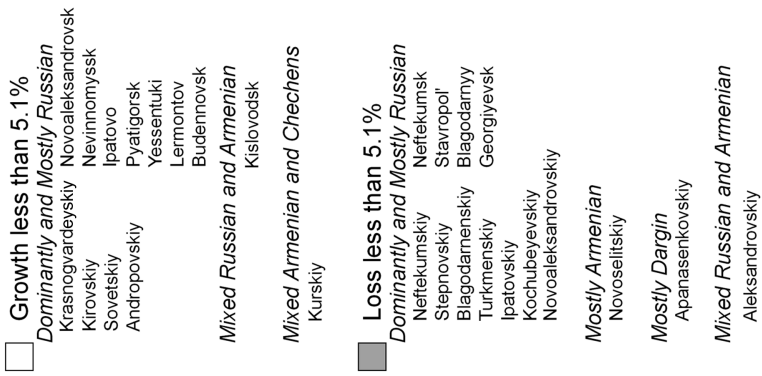

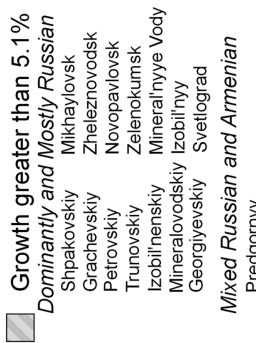

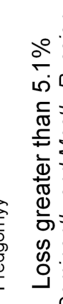

ํ. 돌 के

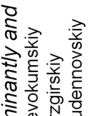

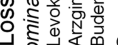

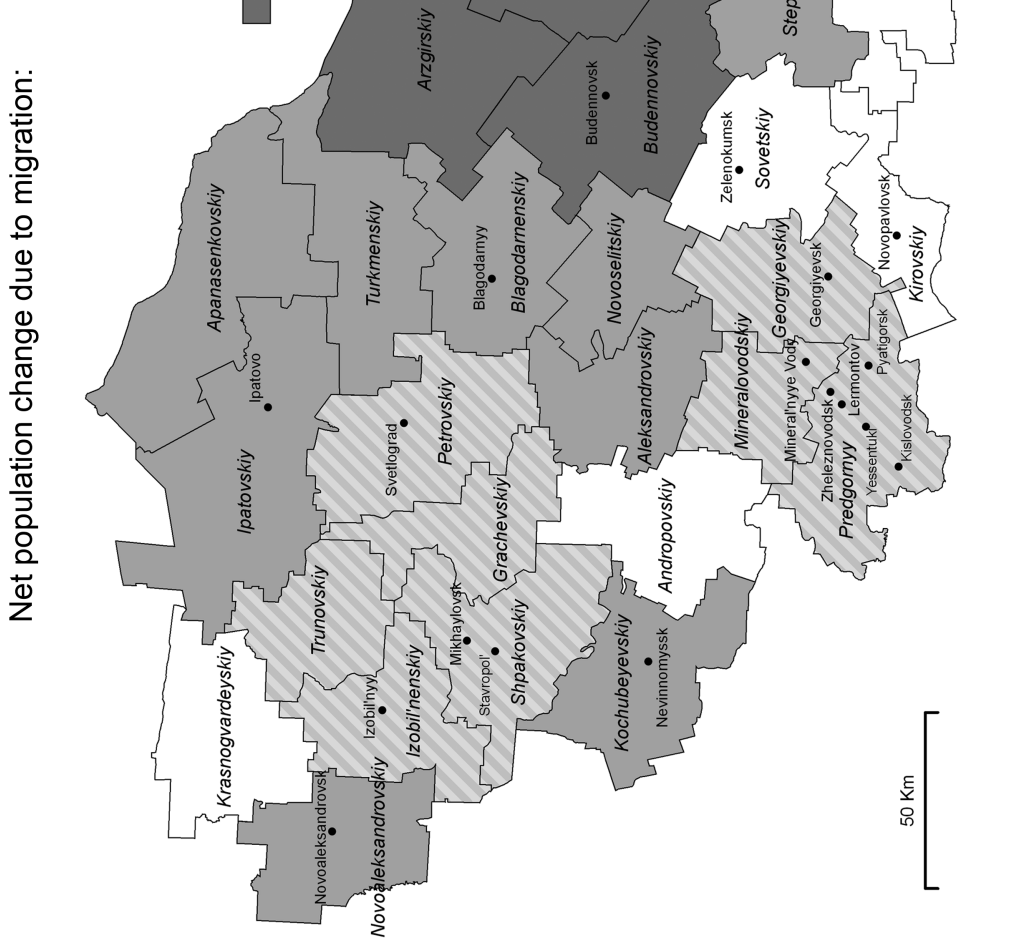


south. During the final years of the Soviet Union, 1988-1992, the new migration processes were solidified under the influence of the mutually reinforcing factors of political change, economic liberalization, military conflict, and the deterioration of inter-ethnic relations (Zayonchkovskaya, 2000). By 1994, net in-migration had increased by 29.3 percent relative to 1989, and just over half of all cities in Stavropol' Kray recorded positive migration balances. Differences were now clearly visible between urban and rural areas (the expected, traditional differentiation) but also among the rayons of the kray, with Stavropol' city retaining the highest intensity of net in-migration (Ryazantsev, 1999).

The late 1990s ushered in still another trend in Stavropol' Kray. For the first time since World War II, most large cities lost population, as they proved increasingly unattractive to migrants during a time of great economic dislocation and catastrophic job loss as industrial and construction enterprises scaled back their activities. Conversely, smaller cities consistently showed higher rates of in-migration, as housing price increases there were not as severe as in the larger cities. Smaller cities in western Stavropol' Kray, in the piedmont region and near the health resorts, registered the highest rates of in-migration. ${ }^{7}$ Migrants during this period appeared to be repelled by multi-ethnic rayons or those near "flash points" in Dagestan, Chechnya, and North Ossetia-Ingushetia.

Also during the second half of the 1990s, the kray's migration balance (in versus out) was only slightly positive. The internal geography of migration also shifted, with marked zones of out-migration in rural rayons of the southeast (Kurskiy, Stepnovskiy), east (Levokumskiy, Neftekumskiy), northeast (Arzgirskiy, Turkmenskiy, Apanasenkovskiy), and northwest (Krasnogvardeyskiy, Ipatovskiy, Novoaleksandrovskiy). More recently (2005), large cities such as Stavropol' and the cities of the Mineral'nyye Vody region (Kislovodsk, Yessentuki, Pyatigorsk) once again have experienced increasing levels of net in-migration, returning to the pattern of the 1960s.

To summarize, the past 35 years have seen a reduction of the rural population of Stavropol' Kray, a trend that corresponds with that in other parts of rural Russia (Ioffe, 2004; Ioffe and Nefedova, 1997; Pallot, 1990; Pallot and Moran, 2000), while cities have seen a flow, then ebb, and now again a flow of in-migrants. ${ }^{8}$ Although the dominant trend is broad agricultural contraction and adjustment to post-Soviet economic realities of privatized markets, the kray also exhibits some special migration features by virtue of its location adjacent to the ethnic regions of the North Caucasus. Examination of the ethnic character of contemporary migration reveals the impact of recent political tensions that have resulted in significant population turnover in some rayons.

\section{ETHNIC STRUCTURE OF MIGRATION AND SETTLEMENT, 1989-2005}

An important feature of migration in contemporary Russia, and indeed in all of the postSoviet space, is its ethnic character. If movement to/from origins and destinations is not proportionate to the shares of various ethnic groups in the broader population, spatial polarization can result. In the post-Soviet world, the (mostly unrestricted) freedom to move is a novel, albeit basic right of a democratic state. But whereas migration was commonplace even in Soviet times, the allocation of territories to titular groups privileged particular ethnic

${ }^{7}$ In-migration and out-migration are measured as the number of movers per 1000 people.

${ }^{8}$ However, the net population gain due to in-migration is now relatively small, only 3,100 for the entire kray in 2005. 
groups, but not others. During the post-Soviet migrations of the 1990s, millions have moved to their titular lands, both the ethnic republics within Russia and, at a more general scale, to Russia from the former republics of the Soviet Union (Zayonchkovskaya, 2000). ${ }^{9}$

Among ethnic republics of the North Caucasus, both rapid population growth and outmigration remain a well-established tradition. Within the latter region, the natural population decrease of ethnic Russians contrasts dramatically with the high natural increase of the Caucasian peoples. Because migration has tended to be ethnic-specific in character, and to specific areas of Stavropol' Kray, the end result is increasing internal differentiation.

During the 1990s, the numbers of Germans and Jews in Stavropol' Kray plummeted as a result of the aggravation of ethno-political conditions, economic collapse, and settlement opportunities abroad. For ethnic Russians, in-migration barely exceeded out-migration, in contrast to groups exhibiting high rates of net in-migration into the kray, most notably Armenians (27.7 in-migrants per 1000 population) and Ukrainians (20.7). ${ }^{10}$ The highest coefficients of out-migration from Stavropol' Kray during the early 1990s were registered by the Chechens (35.8 per 1000), followed by the Dargins (30.2). ${ }^{11}$

After a five-year period of net migration loss in the late 1990s (1995-2000), positive net migration prevailed in Stavropol' Kray during the subsequent half decade (2001-2005), with Dargins now among the most prominent in-migrants. At present (2005), the most salient current characteristics of ethnic migration in the kray are: (1) low net in-migration of Russians and other Slavic peoples; (2) high in-migration of Armenians; (3) renewed out-migration of Chechens after nearly a decade (1996-2004) of in-migration coinciding roughly with the first and second Chechen wars; and (4) continued net in-migration of the Dargins. Among the entire population of net in-migrants to Stavropol' Kray, Russians predominated until 2001, when their share was 72.5 percent of the total, but dropped to 44 percent in 2005 . A trend of "de-Russification," reflecting Russians' low rates of net in-migration and natural increase, is manifest in a noticeable reduction in the ethnic Russian share of the total population, now 82 percent of the total as compared to 84 percent in 1989 and 88 percent in 1979 (TsSU, 1984, pp. 84, 91; Goskomstat SSSR, 1993, pp. 280-299; Rosstat, 2003; see also Tsvetkov, 2006).

Analysis of the ethnic structure of migration in the kray over the past decade indicates that the most important groups are Russians, Armenians, Dargins, Nogays, and Chechens. These groups merit more detailed analysis at the rayon level. In each case, primary attention is devoted to geographical aspects of the migration flows, to the influence of migration on the existing ethnic mix, and to the geography of population change due to migration in cities and rayons of the kray. A summary of the trends by rayon and major city is presented in the map of migration types from 1989 to 2005 (Fig. 1).

\section{Russians}

Events in the broader Caucasus region have had an impact on the migration flow of Russians, first promoting their movement outward from the former Transcaucasian republics (south of the Great Caucasus Range), and then from the republics of the North Caucasus, especially Chechnya. As noted above, Russians have typically been the dominant

${ }^{9}$ Over 25 million Russians lived in the Near Abroad (former USSR outside the borders of the Russian Federation) in the 1990s (see Harris, 1993).

${ }^{10}$ The average net in-migration coefficient for the entire kray was 9.2 per 1000 .

${ }^{11}$ Later in the $1990 \mathrm{~s}$, these migration streams reversed, with both groups registering net in-migration (albeit Dargins for a longer period than Chechens, as described later). 
in-migrating group into Stavropol' Kray, accounting for 60.7 percent of all in-migrants in the mid-1990s and 72.5 percent in 2001 . However, this flow had weakened considerably by 2005, when the corresponding figure for Russians was 44 percent. The waning intensity can be attributed not only to the effects of military actions in the first (1994-1996) and second (1999-present) Chechen campaigns, which impeded the repatriation of Russians (Belozerov, 2005), but also the fact that many of those most capable of migrating from the ethnic republics and Transcaucasus had already done so. Thus, the late 1990s were a time of declining and low rates of natural increase (ca. 5 per 1000) for the Russians, so that by 2001 the Russian population of the kray already was experiencing natural population decrease (of ca. 10,000). Therefore, it is only because of the continued (albeit reduced) in-migration that the absolute number of Russians in the kray in 2001 was higher than in the late 1990s.

As noted by Vitaliy Belozerov (2005), the destinations of Russian in-migrants to Stavropol' Kray has changed during the post-Soviet period. In the early 1990s, 60 percent of Russian migrants went to rural areas but, in subsequent years, the pattern returned to a more traditional distribution, with Russian in-migrants in 2005 moving to towns and cities in proportion to their size and economic attractiveness. However, the cities of Stavropol' Kray, as in other regions of the North Caucasus coping with a severe economic crisis, could not fully absorb a steady, mass migration into their local labor markets, and lacked the resources necessary to provide for new arrivals in the social sphere. Among the cities receiving the greatest numbers of Russian in-migrants were Stavropol', Budennovsk, and Mineral'nyye Vody. ${ }^{12}$

In all, 85 percent of Stavropol's rayons reported net in-migration of Russians over the period 1989-2005. Exceptions included a tier of four rayons along the kray's eastern border-Kurskiy, Levokumskiy, Neftekumskiy, and Arzgirskiy (Fig. 1). While the reasons behind Russian in-migrants' avoidance of these eastern rayons are not completely clear, they probably reflect a combination of poor economic prospects (these are the most marginal agricultural areas in the kray) and an incipient process of ethnic segregation that had gained momentum by the 1990s (Kolossov et al., 2001). ${ }^{13}$ An important feature of the broad period 1989-2005 is the emergence of a trend toward out-migration of ethnic Russians from cities such as Stavropol' and Georgiyevsk (with high housing prices and limited job opportunities) and net in-migration into such industrial/resort centers as Budennovsk, Mineral'nyye Vody, Nevinnomyssk, Kislovodsk, Yessentuki, and Lermontov, as well as the majority of small cities (e.g., Novopavlovsk).

\section{Armenians}

In the 1990s, Armenians ranked second among ethnic groups in terms of the number of total in-migrants into Stavropol' Kray, a position that they have maintained to the present. ${ }^{14}$ From a net in-migration of ca. 4,000 per year in the 1990 s, the numbers have fallen now to about 2,300 annually. According to the 2002 Russian census, Armenians comprised 5.5 percent of the population of the kray, accounting for 13.2 percent of all Armenian residents in Russia.

\footnotetext{
${ }^{12}$ Rural rayons with high rates of Russian in-migrants included Aleksandrovskiy, Blagodarnenskiy, Georgiyevskiy, Ipatovskiy, Kirovskiy, Kochubeyevskiy, Mineralovodskiy, Sovetskiy, and Shpakovskiy.

${ }^{13}$ For example, in 2000-2004, the rayons registering the highest rates of out-migration by Russians were Turkmenskiy, Neftekumskiy, Levokumskiy and Arzgirskiy, all in the east.

${ }^{14}$ The Armenian population of Stavropol' Kray more than doubled between 1989 and 2002, from 70,171 to 149,249 (Narody, 1994, p. 436; Rosstat, 2003). After Russians, Armenians are the most populous ethnic group in the kray.
} 
The present spatial distribution of the Armenian population is a fairly recent phenomenon. Although Armenians have resided in Stavropol' Kray (mostly in cities) for over 200 years, they were concentrated until at least 1979 in areas of traditional settlement in the southwestern portion of the kray (Belozerov and Ganeyeva, 1997). ${ }^{15}$ Since that time, and particularly in the late 1980s, accelerated immigration of Armenians occurred as a result of the Nagorno-Karabakh conflict and related political unrest, as well as the massive Armenian earthquake in $1988 .{ }^{16}$ Persistent migration flows dating from this period can be detected into the city of Nevinnomyssk, as well as into a large number of rural rayons not previously home to appreciable numbers of Armenians (Aleksandrovsk, Blagodarnenskiy, Grachevskiy, and Ipatovskiy). During the period 1989-2005, the Armenian population increased in 88 percent of Stavropol's rayons, with only Turkmenskiy, Levokumskiy, and Apanasenkovskiy rayons along the eastern borders with Dagestan and Kalmykia and Novoselitskiy Rayon in the center of the kray recording net Armenian out-migration (Fig. 1). As a result, by 1989 the share of the Armenian population residing in the three main centers of traditional settlement (Mineral'nyye Vody, Budennovsk, and in Kurskiy Rayon) had dropped to 79 percent (Belozerov, 2005).

More recently, due to the spillover of terrorist actions from the Chechen conflicts, isolated cities such as Budennovsk have held little attraction for Armenians. Armenian net outmigration within the last few years now also is a characteristic of isolated rural rayons such as Arzgirskiy, Blagodarnenskiy, Kirovskiy, Krasnogvardeyskiy, and Kurskiy, as well as small cities like Ipatovo, Neftekumsk, and Novoaleksandrovsk. Thus, in 2005 the area of net Armenian in-migration once again closely coincides with their traditional settlement area.

\section{Dargins and Chechens}

Census data indicate an acceleration in the population growth of North Caucasian peoples in Stavropol' Kray, both as a function of in-migration and high rates of natural increase. The number of Dargins in the kray, for example, jumped from 6,000 in 1970 to 32,400 in 1989 and 40,200 in 2002. The Dargin diaspora in the kray is one of the largest in Russia, and by the census of 1979, more than 40 percent of Dargins who lived outside the Republic of Dagestan resided in Stavropol' Kray (Belozerov, 2000).

Dargin in-migrants initially clustered in Levokumskiy, Neftekumskiy, and Arzgirskiy rayons, near the Dagestani border in the eastern part of the kray. These three rayons were home to 57 percent of the Dargin diaspora in the North Caucasus at the end of the Soviet period (ibid.), and included areas concentrating on sheep rearing, a traditional Dargin activity in their Dagestani homeland. ${ }^{17}$ In the first stage of rural settlement, only men migrated to tend the flocks, but as the immigration developed, sheep-breeding extended to the kutan model. ${ }^{18}$ In addition, on the dry steppes of eastern Stavropol' Kray, some small areas have retained a cattle-breeding specialization based on Chechen and Dargin labor imported in the

${ }^{15}$ In 1979, 85 percent of Armenians in the kray resided in three principal locations-Mineral'nyye Vody, Budennovsk, and Kurskiy Rayon in the far southeast (Belozerov, 2005).

${ }^{16}$ For background on the impacts of these factors on Armenia's current population, see Rowland (2007).

${ }^{17}$ In general, North Caucasian immigrants dominate this form of agriculture. As the indigenous (Russian) rural population migrated away from the peripheral eastern rayons of the kray, and as the sheep numbers increased, the demand for labor in this non-prestigious activity was met by Dagestani, Chechen, and Karachay immigrant herdsmen (Belozerov, 2000).

${ }^{18} \mathrm{~A}$ kutan is a small hamlet where the shepherds spend the winter with their flocks, and thus represents a less transient mode of settlement that could include women and children for at least part of the year. 
1980s and 1990s. By the 1989 census, Dargins constituted the majority in 24 villages and Chechens in 23. Although all were categorized as settlements, in a functional sense they were state or collective farms. Not only did Chechens and Dargins move into traditionally Russian-dominated regions, but they also settled in territories inhabited by other minorities, such the Nogay and Turkmen, who also specialized in stock breeding. This immigration led to a kind of economic competition that assumed an ethnic character, especially in Turkmenskiy and Neftekumskiy rayons. More recently, since roughly the mid-1990s, rural Caucasian immigrants have also begun to move to towns and seek employment in construction, trade, and commercial enterprises, much of it linked to the shadow economy.

Beginning in the 1980s, the kray's Dargin population grew and began to diffuse to the north and west as a result of the worsening ethno-political situation in the North Caucasus republics and deteriorating economic options and political events in Dagestan. However, high levels of Dargin out-migration from Stavropol' Kray prevailed during the 1990s from the areas of recently expanded settlement, and by 2005 the pattern of migration had reverted to traditional form: although Dargin numbers are still increasing in the eastern rayons and large cities of Stavropol' Kray, they are decreasing in the western rural areas.

Chechens arrived in Stavropol' Kray somewhat later than the Dargins. In the 1960s, more Chechens departed their republic for Rostov Oblast than for adjacent Stavropol' Kray, where they concentrated in Kurskiy Rayon on the Chechen border. In the 1970s, Chechen inmigrants tended to settle in a ring of rural rayons surrounding the city of Stavropol' (Belozerov, 2000). By the 1980s, the profile of migration changed to include more families and women of child-bearing age, so that by the early 1990s, Chechen population growth in the kray was mostly due to natural increase. The migration balance reversed after the 1989 census, with Chechens exhibiting a trend toward net out-migration from the Kray. This appears to have offset the impetus provided by natural increase, as there are now a couple of thousand fewer Chechens in Stavropol' Kray than in 1989.

\section{Nogays}

The Nogay (named for the grandson of Genghis Khan) are a Turkic people descended from Tatar settlers of the steppes on the northern and western side of the Caspian Sea. After the conquest of the region by the expanding Russian Empire, the Nogay were moved to the south and today are concentrated in Nogayskiy Rayon of northern Dagestan. A significant minority of the Nogay (roughly one-third of the total) resides in the eastern rayons of Stavropol' Kray, especially in Neftekumskiy Rayon, where they predominate in 10 villages in this sparsely settled region. A secondary minor concentration can be seen in the Mineral'nyye Vody area where, as in the eastern regions, they are almost exclusively a rural people. ${ }^{19}$

Unlike the Chechens and Dargins, the distribution of the Nogay has been stable, and population increase has resulted from the growth in numbers in existing settlements. In response to the increase in the Nogay population, there has been a related out-migration of other groups, especially Russians, from these nodes of settlement. Small but representative surveys in the rayons of eastern Stavropol' Kray by Vladimir Kolossov and colleagues (Kolossov et al., 2001) revealed the concerns of local Russians about population changes. Specifically, they

${ }^{19}$ Outside of Dagestan and Stavropol' Kray, Nogay constitute a plurality of the population in northern part of Karachay-Cherkessia (see Fig. 4 in the preface to this special issue). 
noted the significant increase in the number of Caucasian and Nogay immigrants that were moving out of the national republics to the south at a time when the local economy was in the throes of a major recession following the end of the Soviet-style planned economy. Although the population data suggest a process of de-Russification in these rayons, ${ }^{20}$ the reasons underlying these changes are not completely clear. Speculation about the motives of Russian outmigrants on the basis of aggregate data is suspect due to the ecological fallacy (imputing aggregate relationships to individuals). Our December 2005 opinion survey, designed to capture and reflect the variety of localities of the kray while remaining representative of the overall population by a stratified sample design, can offer more insights into these motivations and measure the relative importance of economic and political factors.

\section{MIGRATION INTENTIONS AND MOTIVATIONS}

The survey on which the analysis of individual migration intentions and motivations in Stavropol' Kray was based was distributed in December 2005 to a representative sample of 810 adults distributed proportionately to populations in 32 communities. Because the kray's large territory envelops a variety of geographies, ${ }^{21}$ it is to be expected that the causes and directions of movements are highly variable in this multi-ethnic territory. We expected to find both a set of economic factors (typical for migration universally) as well as special local conditions of contiguity to a conflict zone to be helpful in understanding migration patterns.

The first question posed by the survey about migration asked respondents if they had changed residence in the previous 15 years, dating back to the break-up of the Soviet Union. The mean for the "yes" response was 38.4 percent, ranging across the 32 sample points from 4.9 to 66.8 percent. The geographic distribution of the mean response by sampling unit showed no obvious correlations with regional, urban-rural, or city size factors (Fig. 2). Such a pattern (or more precisely, the lack of one) is not unexpected given the account of aggregate trends presented in the previous sections of the paper. Multiple factors have impinged on the usual rural-to-urban trends that are evident in Russia as a whole, especially the complex patterns of ethnic chain migrations from the Caucasian republics to the south and the significant upheavals in the industrial and tourist economies after 1991. The tourist complexes of the Mineral'nyye Vody area generally exhibit higher than average migration turnover, as do industrial cities such as Nevinnomyssk, Neftekumsk, and Budennovsk. ${ }^{22}$

In choosing predictor variables for the modeling of past migration, we included the usual demographic factors such as age, gender, education, and economic status. These measures are well-known, important predictors of migration, with younger people more likely to move than older, males more than females, better educated more than less educated, and relatively more affluent more than the less well off. To these factors, we added measures of evaluation of future economic prospects, both for the individual respondent and for his/her evaluation of the community, and whether the person was an urban or rural resident. We also measured attachment to place by including a variable that indicated whether the respondent considered his birthplace as "home." We expected that people with optimistic views and residents in urban areas, as well as those not attached to the birthplace, were more likely to move. To get

${ }^{20}$ See Vendina et al. (2007, p. 197) in this special issue.

${ }^{21}$ These range from the drier piedmonts where grazing is prominent in the south, to tourist-oriented spa cities in the southwest, to wide open steppes to the north, to dry plains of the east (as well as from large industrial and administrative centers to small isolated agricultural villages).

${ }^{22}$ The lowest values are found in small agricultural communities in the steppes. 


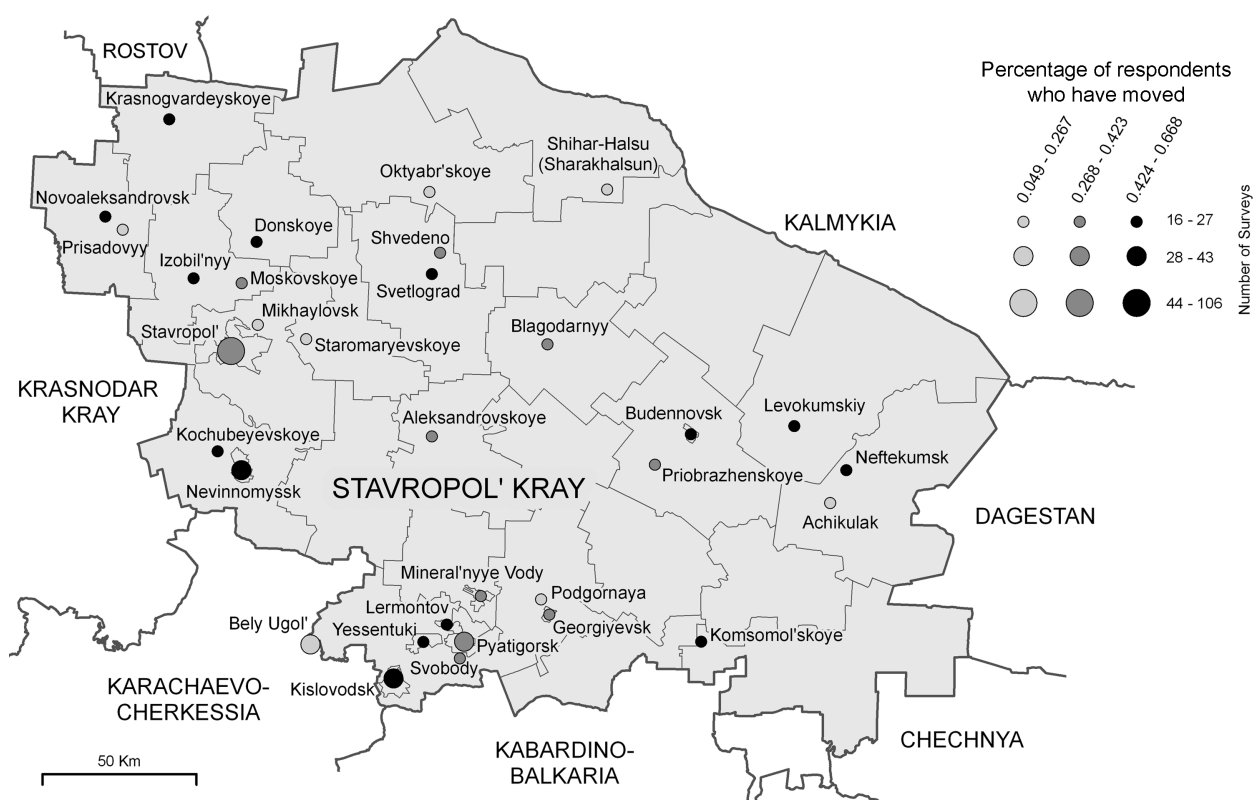

Fig. 2. Distribution of responses to question of whether the respondent has moved since 1990 in the 32 sampling points of Stavropol' Kray. Mean response is 38.4 percent. Source: December 2005 survey (see text for details).

some sense of the possible impact of tense inter-ethnic relations, we included Russian nationality as a variable, as well as measures of the current state and trend in ethnic relations as perceived by the respondent. Although we expected those respondents who reported a poor state of ethnic relations to be more likely to move in the future, the expected relationship with past moves was not evident. Finally, we included two measures that summarized personal conflict experiences (i.e., whether the respondent's life was influenced by the regional conflicts) and the respondent's overall view of the social, economic, and political situation in the kray. While there are clear expectations that people are more likely to move from negative situations, the relationship with previous moves is less clear because the current residence may not represent much of an improvement.

Of the 13 predictors in the model, only 5 show a significant relationship with past moves (Table 1). ${ }^{23}$ As expected, older persons have moved less than younger respondents, and people more attached to their place of birth also have not moved as much as others. Females have moved significantly less than males. Those who evaluate the state of ethnic relations to be poor are more likely to have moved, while those who rate their personal prospects as better are less likely to have moved. All of these factors conform to the expected relationships, and in this regard Stavropol' Kray is not exceptional. What is somewhat surprising, however, is the lack of explanation from the perceived state of political and social relations or from the set of predictors connected to the state of the local economy. These variables are expected to be more useful in projecting future migration behavior than past moves. However, migrants 
Table 1. Predicting Change in Residence in Stavropol' Kray in a Logit Model ${ }^{\mathrm{a}}$

\begin{tabular}{lcccc}
\hline \hline \multicolumn{1}{c}{ Predictor } & Coefficient & Standard error & $t$-value & Prob. $T$ \\
\hline Age & \multicolumn{3}{c}{ Significant variables } \\
Home is birth place & -.021 & .007 & -3.19 & .003 \\
State of ethnic relations & -.458 & .165 & -2.77 & .009 \\
Gender & .373 & .107 & -2.62 & .013 \\
Personal prospects & -.303 & .143 & 2.60 & .014 \\
& & .127 & -2.38 & .024 \\
Russian & -.413 & .259 & & \\
Trend of ethnic relations & -.189 & .161 & -1.59 & .121 \\
Econ. prospects for kray & -.117 & .145 & -1.17 & .249 \\
Education & .025 & .061 & -0.81 & .427 \\
Village residence & -.098 & .255 & 0.42 & .678 \\
Changed by violence & -.050 & .174 & -0.39 & .703 \\
Family material status & .002 & .159 & -0.29 & .777 \\
Situation in kray & -.008 & .206 & 0.01 & .990 \\
Constant & 3.137 & .893 & -0.04 & .968 \\
\hline
\end{tabular}

${ }^{a}$ Dependent variable denotes whether the respondent moved or not since 1990 (38.4 percent of the sample of 810 persons reported a move).

Source: Survey of 810 respondents in Stavropol' Kray in December 2005. See pp. 258-259 for details on the survey design and sample.

may have left communities with tense ethnic relations or poor economic conditions only to find that their current residences still suffer from these circumstances. Furthermore, in a dynamic region like Stavropol' Kray, economic reasons for moving might clash somewhat with the desire to find a destination with better ethnic relations than the one the respondent left. In other words, the correlation between the state of ethnic relations and the state of the local economy is not predictable or necessarily strong.

Another key migration question in the survey asked if the respondent wished to move in the succeeding two years, and an average of 29.6 percent replied affirmatively. ${ }^{24}$ The geographic distribution of these responses reflects an urban bias (Fig. 3). Larger towns and cities, especially in the Kavkaz Mineral'nyye Vody region showed above-average values, and agricultural villages in the steppes below-average ones. Urban areas, in general, have higher migration turnover but in the case of Stavropol' Kray, the normal rate of movement is increased by economic dislocations following the disintegration of the Soviet Union (especially in industry and tourism) and the departure of ethnic Russians for economic opportunities elsewhere (with subsequent infilling of these slots by Caucasian immigrants).

As was the case for previous moves, we expected an individual's demographic characteristics, economic status and prospects, evaluation of the local economic environment, residence (rural or urban), and perception of local ethnic and social relations to influence the decision to move. We expected the key variable to be the response to the question regarding the greatest contemporary dangers in the North Caucasus. Among the options (lack of

${ }^{24}$ The ratio ranged from zero in the rural Oktyabr'skoye village in the steppe rayon of Ipatovskiy to 64.7 percent in the city of Georgiyevsk in the southern part of the kray. 


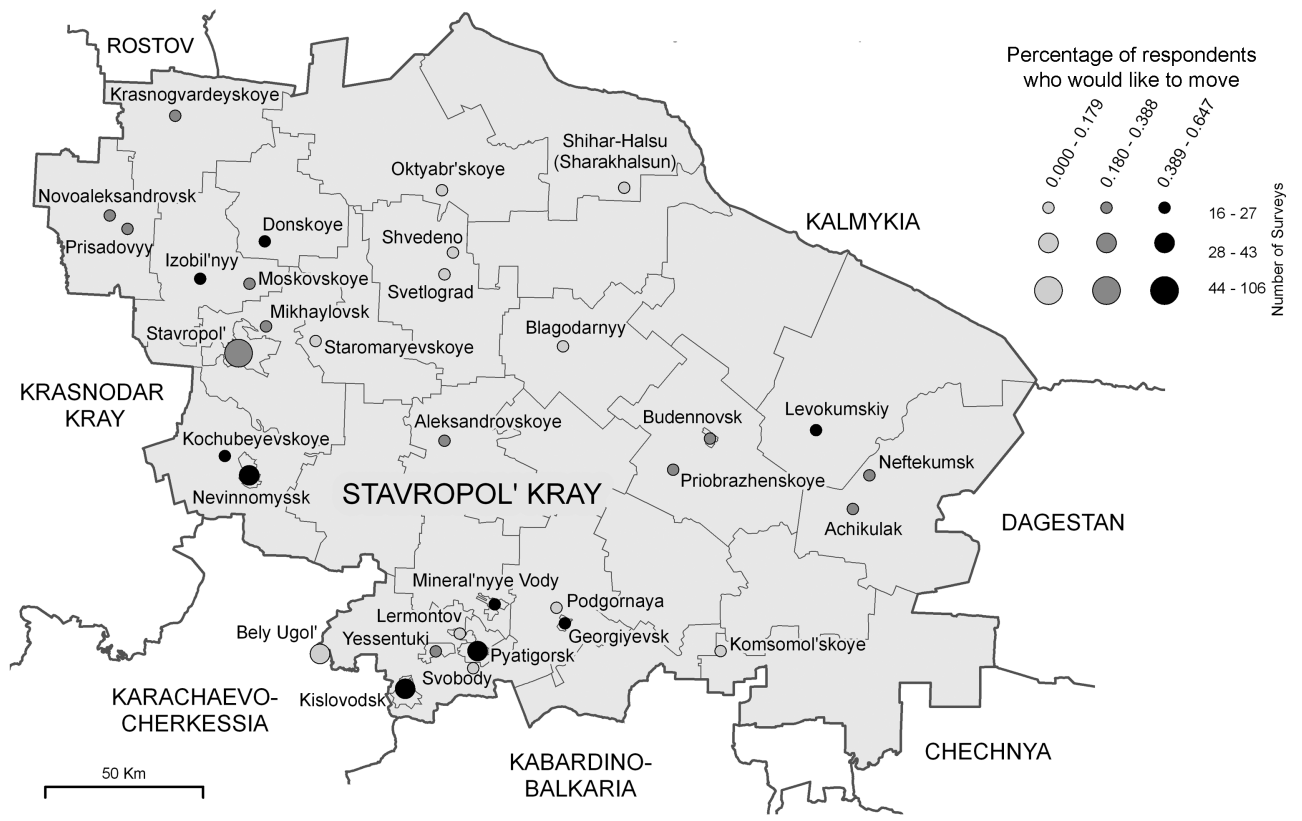

Fig. 3. Distribution of responses to the question of whether the respondent would like to move in the next two years in the 32 sampling points of Stavropol' Kray. Mean response is 29.6 percent. Source: December 2005 survey (see text for details).

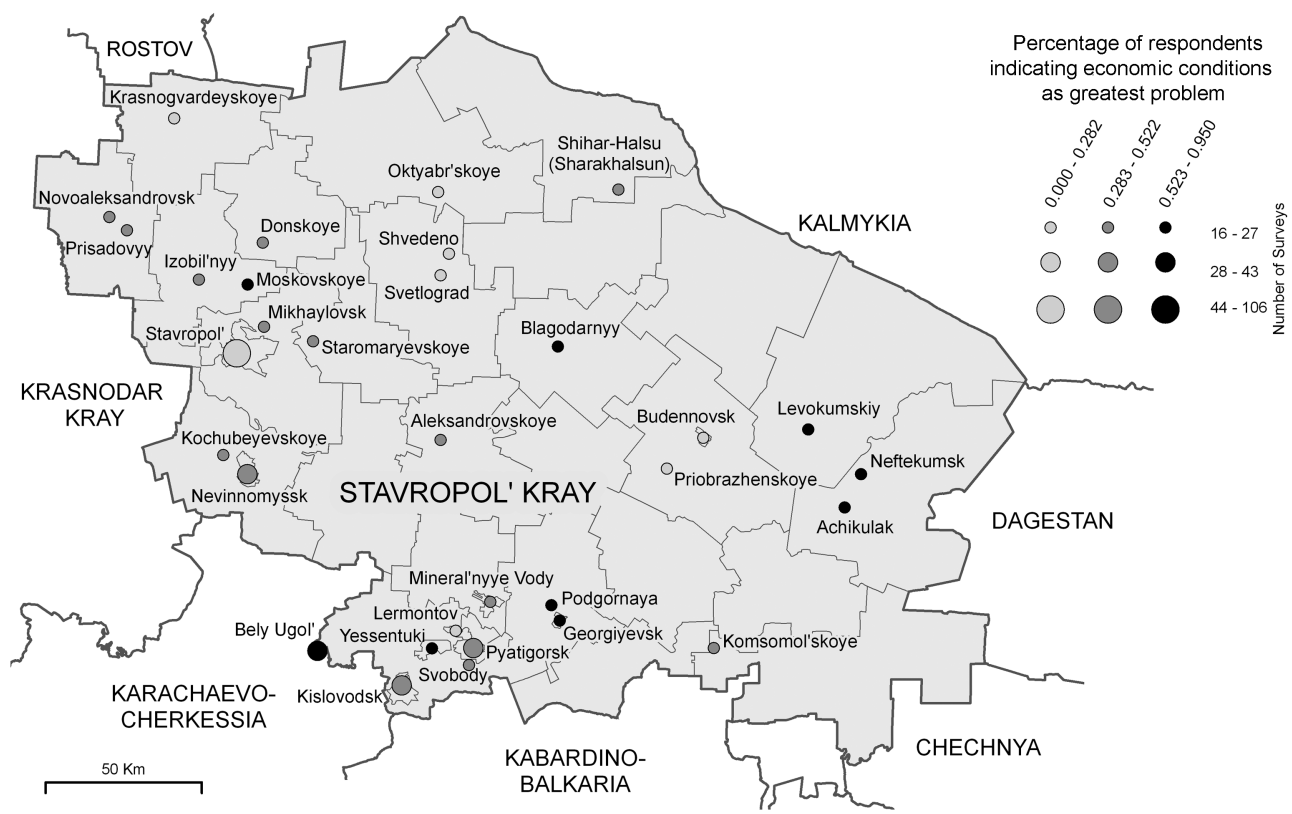

Fig. 4. Distribution of responses to the question regarding the main problems facing the peoples of the North Caucasus. The map shows the average response in the 32 sampling points of Stavropol' Kray to the option "lack of economic development." The mean response for the entire kray is 47.5 percent. Source: December 2005 survey (see text for details). 
Table 2. Predicting Migration Preference (stay or move) in Stavropol Kray ${ }^{\mathrm{a}}$

\begin{tabular}{lcccc}
\hline \hline \multicolumn{1}{c}{ Predictor } & Coefficient & Standard error & $t$-value & Prob. $T$ \\
\hline Main problem, local & \multicolumn{3}{c}{ Significant variables } \\
$\quad$ economy & .509 & .206 & 2.47 & .019 \\
Age & -.032 & .013 & -2.45 & .020 \\
Occupational rank & -.210 & .102 & -2.06 & .048 \\
Family material status & -.394 & .204 & -1.93 & .063 \\
& & Control variables & & \\
Rural residence & -.452 & .341 & -1.33 & .195 \\
Gender & -.234 & .188 & -1.24 & .225 \\
Situation in kray & .220 & .178 & 1.23 & .227 \\
Educational level & -.068 & .060 & -1.13 & .266 \\
Home is birth place & -.190 & .271 & -0.70 & .487 \\
Russian & .084 & .323 & 0.26 & .795 \\
Generalized trust & -.015 & .353 & -0.04 & .952 \\
Constant & 3.052 & 1.23 & 2.49 & .018 \\
\hline
\end{tabular}

apependent variable is whether the respondent will move in the next two years (sum of "very likely" and "likely" responses $=29.6$ percent of the total).

Source: Survey of 810 respondents in Stavropol' Kray in December 2005. See pp. 258-259 for details on the survey design and sample.

economic development and jobs, terrorism, crime, increased ethnic separatism, and political corruption), "lack of economic development" was by far the first choice at 47.5 percent ("political corruption" was next at 21 percent). The distribution of the response to the "poor economic conditions" option is depicted in Figure 4. The lowest value, zero in Budennovsk, is not unexpected because 77 percent of respondents in that city chose terrorism as the greater danger. ${ }^{25}$ The highest value of 95 percent is seen in Blagodarnyy, a small town in the agricultural belt. Overall, however, the highest values are concentrated again in the tourist region of Kavkaz Mineral'nyye Vody in southwestern Stavropol' Kray.

The logit model identified only four significant predictors of intention to move (Table 2). Age appeared again as a strong predictor, with younger respondents significantly more likely to state an intention to migrate within two years. The other three significant predictors are centered on the economic conditions of the respondent (family material status and occupational rank) and whether the respondent sees the lack of economic development as the main danger facing the region. Poorer people and those with lower occupational rank stated a higher propensity to move, as did those who are most concerned about the weak economic conditions of the region. Factors such as gender, Russian nationality, attachment to birthplace, education, perception of the overall situation in the kray, urban-rural residence, and generalized trust levels are not significant predictors of migration intentions in Stavropol' Kray.

${ }^{25}$ Budennovsk was the site of a massive hostage-taking terrorist incident in June 1995, in which Chechen fighters led by Shamil Basayev held more than 1,800 people hostage in the city hospital for six days. More than 400 people were injured and 147 lost their lives before then-Prime Minster Viktor Chernomyrdin negotiated the release of hostages in exchange for safe passage of the hostage-takers back to Chechnya (Coalson, 2005). 
These analyses of individual experiences with migration and migration intentions complement the aggregate analysis reported earlier. The results also support the conclusions of the paper by Eldarov et al (2007) in this special issue concerning the redistribution of the population in Dagestan (the republic that adjoins Stavropol' on the east) regarding the importance of economic factors in explaining aggregate movements, ${ }^{26}$ and the significance of stage in the life cycle in all settings. Although many authors (e.g., Dunlop and Menon, 2006) have emphasized the upheaval caused by the Chechen wars on the adjoining regions, the patterns of migration in Stavropol' Kray mostly conform to the same set of factors found elsewhere in Russia, although they are complemented by specific ethnic chain migration in rural communities near titular regions that have seen significant outmigration.

\section{ETHNO-DEMOGRAPHIC AND MIGRATION PROCESSES IN KRASNOGVARDEYSKIY RAYON}

We can illustrate current developments in demography and migration in the steppe regions of the North Caucasus with a detailed account of one such rayon-Krasnogvardeyskiy, the most northwesterly unit in Stavropol' Kray (see Fig. 1 for location). The scarcity of official statistics makes it difficult to provide detailed insights into the demographic and migration behavior of peoples in small geographic units because most of it is available at the more generalized scale of federal subjects (oblasts, republics, krays) and large cities. Obtaining data at the rayon level is a labor- and time-consuming process that typically requires the development of a specific system for data collection and information processing as well as field work and/or the cooperation of local authorities. Despite these challenges, such data are quite useful in evaluating the demographic future of isolated rural areas on the southern Russian steppe. ${ }^{27}$

Our sample rayon, Krasnogvardeyskiy, has always been characterized by high agricultural productivity due to both favorable agro-climatic conditions and competent administration in agricultural production (Srednik and Panin, 2004). Secondly, the rayon benefits from a strategic geographical location, along the main transportation corridor between Rostov-onDon and Stavropol' city. Krasnogvardeyskiy Rayon is also the birthplace (village of Privol'noye) of the 1990 Nobel Peace Prize winner and former Soviet President, Mikhail Gorbachev, whose legacy in Russia remains somewhat ambiguous. Directly or indirectly, Gorbachev's personality and legacy for a long time influenced the development not only of his native village, but also the entire rayon.

Like most parts of the kray, Krasnogvardeyskiy's demographic evolution is now marked by a growing loss of population due to natural decline and net out-migration, a situation not unlike many parts of the American Great Plains. In 2005, just over 42,000 persons lived in the rayon, following several years of population decline. As elsewhere in Russia, the complex and dramatic social and economic transitions since 1991 substantially affected reproductive behavior. Although during the intercensal period of 1979-1989, the rayon actually registered natural population increase ( 2.1 percent), the small gain was followed by the first

${ }^{26}$ I.e., movements from rural to urban areas, and from cities of declining industry to growing service/administrative centers such as Stavropol' city.

${ }^{27}$ Additionally, such information can assist in the most basic planning and forecasting activities for these (typically poor) administrative units (Zayonchkovskaya, 2003). And even within rayons, populated places tend to be quite heterogeneous, with rayon averages concealing wide discrepancies. Changes occurring in populated places tend to be of widely differing character and depend on an entire range of factors (age and ethnic composition, location, and standard of living) that require close scrutiny. 
indication of natural population loss in 1990. Natural population decline peaked at 8.7 per thousand in 1997, less severe than that for the kray as a whole or for Russia, but cumulatively, natural losses reduced the overall population by over 2,000 between 1990 and 2002. Recent figures indicate a continuation of natural population decrease, with the number of deaths more than double that of births in 2004.

Natural population loss reflects a combination of a reduction in the number of births ${ }^{28}$ and an acceleration of mortality rates, although in the case of Krasnogvardeyskiy, it is primarily the latter. Reflecting a broader malaise in Russian society, ${ }^{29}$ the elevated incidence in mortality has extended down to working-age cohorts, with recent statistics indicating a sharp rise in deaths due to various cancers, tuberculosis, alcoholism, and poor medical treatment. The age structure of the rayon is also more imbalanced than that of Russia as a whole, with pensioners comprising 33 percent of the population and children only 14 percent - the latter significantly lower than the average for Russia or the kray as a whole.

Prior to the mid-1990s, Krasnogvardeyskiy Rayon's net migration balance was positive, ${ }^{30}$ attracting in-migrants from a diverse hinterland including the ethnic republics of North Caucasus, Transcaucasia, Central Asia, and Ukraine. After the dissolution of the Soviet Union, in-migration assumed a different character, with migrants consisting predominantly of people forced from their homes in Central Asia and the Caucasus region due to ethnic-based conflicts. As a result of its location as the nearest Russian-dominated region to the "hot spots" of the Caucasus, Stavropol' Kray became a crossroads of migration and received more migrants than other similarly sized subjects of the Russian Federation. ${ }^{31}$ By the mid-1990s, however, this flight had ebbed and the migration balance began to reverse. At present, out-migration is the norm in Krasnogvardeyskiy Rayon ${ }^{32}$ and this negative trend is expected to continue, even in the face of rising incomes accompanying Russia's economic recovery. Together with natural population loss and aging, the rayon's overall population can be expected to drop sharply in the future (by even as much as 37 percent by 2015). ${ }^{33}$

\section{CONCLUSION}

Falling (and now largely negative) rates of natural population increase among ethnic Russian populations combined with an increase in the percentage share of Caucasian peoples in Stavropol' Kray are dramatically altering the structure of the population at the beginning

${ }^{28}$ In the late 1980s, the number of births averaged ca. 585 annually, but at present the figure is only ca. 380 .

${ }^{29}$ As reported elsewhere (e.g., Field and Twigg, 2000; Eberstadt, 2004; Pavlovskaya, 2004), overall health status is declining in Russia due in part to the noticeable reduction in the quality of life of most of the population (low wage levels, worsening living conditions, more stressful labor activities and decreased leisure, and declining quality and supply of food) generating a reduction in health and hygiene characterized by some observers as a public health crisis.

${ }^{30}$ For the decade 1990-2000, there was net in-migration into the rayon of ca. 5,000 (ca. 13,000 immigrants and 5000 emigrants). However the peak year (1,152 net in-migrants in 1992) was early in the period.

${ }^{31}$ Rural localities in the kray with good economic prospects that were most distant from the Caucasus flashpoints, such as Krasnogvardeyskiy, were particularly attractive.

${ }^{32}$ Out-migrants traditionally have gravitated to the city of Stavropol', with a much smaller number departing for nearby regions (largely Krasnodar Kray, Rostov Oblast, and other provinces of southern Russia).

${ }^{33}$ Based on existing population numbers and recent trends, and using a Markov chain model for projections, we can forecast expected population totals for the rayon and its constituent parts. According to the most optimistic scenario, the rayon's overall population will fall to 36,500 by 2015 . An intermediate scenario projects a population decline to ca. 31,000, whereas the most pessimistic scenario projects a loss to 26,500 . Several villages and other settlements with current populations of less than 500 may disappear entirely. 
of the $21^{\text {st }}$ century. Given negative natural population growth in most rayons and the aging of the population, future demographic projections for Stavropol' are similar to most other subjects of the Russian Federation (population decline). What distinguishes the kray is the increasing share of non-Russians and a regional stratification of the population along ethnic lines. Taken to an extreme, this sorting could lead to ethnic spatial polarization, although because job opportunities remain largely in the major cities (Stavropol' and those of the Kavkaz Mineral'nyye Vody region), future in-migration to these sites is likely to exhibit a mixed ethnic character. Conversely, as in the case of Dagestan (Eldarov et al., 2007), rural areas likely will experience increasing ethnic segregation.

In a recent paper, Dunlop and Menon (2006) warn about the spread of the conflicts from Chechnya, now more stabilized than five years ago, to the adjoining Russian territories, including Stavropol' Kray. They conclude that the overall "picture is disturbing" (p. 97) and state (p. 109) that "the entire North Caucasus is awash in violence and turmoil, and there is little reason to believe, despite the recent gains the Kremlin seems to have made in Chechnya, that things could get better," although the ratio of 1,180 military and police per 100,000 population makes the region "the most militarized in the world" (p. 110). Our study of Stavropol' Kray, both the aggregate data and the survey of the residents, echoes a concern expressed in the Dunlop-Menon article about the widespread poverty that nearly half of the residents consider to be the greatest single danger for the region. But unlike the DunlopMenon view, most residents are not as concerned about the nature of ethnic relations or about the ongoing conflict in neighboring Chechnya. Like other residents of Russia, most residents of the kray busy themselves with the daily activities of gaining a basic living. In Stavropol' Kray, 64 percent chose the option, "life is difficult but it's possible to live" as the best description of their current material status; another 22 percent chose "it's impossible to tolerate the current situation."

Despite some changes in the ethnic composition of Stavropol' Kray (and unlike the ethnic republics to the south), Russians continue to constitute a strong majority of the population, about 82 percent. The past decade has seen an increase in the number of members of the titular groups from the ethnic republics but the change is quite slow and is only pronounced in certain rayons in the eastern part of the kray. The more prominent population dynamic is the overall shift of inhabitants from rural areas to cities, both in the kray and elsewhere in Russia. In this respect, Stavropol' Kray is more typical of a Russian oblast than a North Caucasian territory. Continued out-migration is mostly dependent on economic options in the face of widespread and pervasive poverty, high unemployment, and the low pay prevailing in agricultural jobs. Until that situation is reversed, the projection is that current trends will lead to a greater concentration of population in a few favored locations (e.g., Stavropol' city) and an emptying of most rural communities and some declining industrial centers.

\section{REFERENCES}

Belozerov, Vitaliy S., Etnodemograficheskiye protsessy na Severnom Kavkaze (Ethno-demographic Processes in the North Caucasus). Stavropol', Russia: Stavropol' State University Press, 2000.

Belozerov, Vitaliy S., Russifikatsiya i derussifikatsiya: Ethnicheskaya karta Severnogo Kavkaza vchera i segodnya (Russification and Derussification: The Ethnic Map of the North Caucasus Yesterday and Today). Moscow: Haugs, 2005.

Belozerov, Vitaliy, Lyubov' P. Belozerova, and Petr P. Turun, Evolyutsiya rasseleniya Stavropol'ya $i$ Karchayevo-Cherkessii (Evolution of Settlement in Stavropol' Kray and KarachayevoCherkessia). Stavropol', Russia: Stavropol State University Press, 1993. 
Belozerov, Vitaliy and Yelena Ganeyeva, Migratsionnyye protsessy na Stavropol'; Problem' rasseleniya: Istoriya i sovremennost' (Migratory Processes in Stavropol' Kray: The Problems of Settlement—History and the Present). Moscow: Sbornik Nauchnykh Statyey, 1997, 103-109.

Belozerov, Vitaliy S. and Aleksandr N. Panin, "Evolyutsiya e ethomigratsionnykh protsessov na Severnom Kabkaze (Evolution of Ethno-migration Processes in the North Caucasus)," in Mezhdunarodnoye Nauchnoye Sobraniye na "Problem' migratsim i opyt yeye regulirovaniya $v$ poli-etnicheskom Kavkazskom regione (International Scientific Conference on 'Problems of Migration and Experience in Its Regulation in the Polyethnic Caucasian Region'). Stavropol', Russia: Stavropol' State University Press, 2003, 34-38.

Belozerov, Vitaliy S. and Aleksandr N. Panin, "Monitoring ethodemograficheskikh protsessov v Yuzhnom federal'nom okruge (Monitoring Ethnodemographic and Migration Processes in the Southern Federal Okrug)." ArcReview, 3:6-7, 2006.

Coalson, Robert, "Russian Town Marks $10^{\text {th }}$ Anniversary of Terrorist Raid" [http://www.rferl.org/ features/], June 14, 2005.

Dunlop, John B. and Rajan Menon, "Chaos in the North Caucasus and Russia's Future," Survival, 48, 2:97-114, 2006.

Eberstadt, Nicholas, "Russia's Demographic Straitjacket," SAIS Review, 22, 2:9-25, 2004.

Eldarov, Eldar M., Edward C. Holland, Zaid M. Abdulagatov, Sharafudin M. Aliyev, and Zagir V. Atayev, "Resettlement and Migration in Post-Soviet Dagestan," Eurasian Geography and Economics, 48, 2:226-248, 2007.

Field, Mark G. and Judyth L. Twigg, eds., Russia's Torn Safety Net: Health and Social Welfare during the Transition. New York, NY: St. Martin's Press, 2000.

Goskomstat SSSR, Itogi vsesoyuznoy perepisi naseleniya, 1989 goda, tom VII, natsional'nyy sostav naseleniya SSSR, chast' 1 (Results of the 1989 All-Union Census of Population, Vol. VII, Nationality Composition of the Population of the USSR, Part 1). Minneapolis, MN: East View Publications, 1993.

Harris, Chauncy D., "The New Russian Minorities: A Statistical Overview," Post-Soviet Geography, 34, 1:1-27, 1993.

Ioffe, Gregory, "Review of Tatyana Nefedova, Sel'skaya Rossiya na Pereput'ye (Rural Russia at a Crossroads)," Eurasian Geography and Economics, 45,6:470-473, 2004.

Ioffe, Grigory and Tatyana Nefedova, Continuity and Change in Rural Russia. Boulder, CO: Westview Press, 1997.

Ioffe, Grigory and Tatyana Nefedova, "Areas of Crisis in Russian Agriculture: A Geographic Perspective," Post-Soviet Geography and Economics, 41, 4:288-305, 2000.

Ioffe, Grigory and Tatyana Nefedova, "Marginal Farmland in European Russia." Eurasian Geography and Economics, 45, 1:45-59, 2004.

Kolossov, Vladimir A., Tamara A. Galkina, and Alekey D. Krindatch, “Territorial'naya identichnost' i mezhetnicheskiye otnosheniya (Na primere vostochnykh rayonov Stavropol'skogo kraya) (Territorial Identity and Inter-ethnic Relations [The Case of Eastern Rayons of Stavropol' Kray])," Polis (Political Studies), 11, 2:61-78, 2001.

Masliyev, Rostislav O., Geoinformatsionnyy monitoring migratsionnykh protsessov v Stavropol'skom kraye (Geo-information Monitoring of Migration Processes in Stavropol' Kray). Unpubl. Ph.D. dissertation in Geographical Sciences, Stavropol' State University, 2006.

Narody Rossii: Entsiklopediya (Peoples of Russia: Encyclopedia). Moscow, Russia: Nauchnoye izdatel'stvo Bol'shaya Rossiyskaya entsiklopediya, 1994.

O’Loughlin, John and Gearóid Ó Tuathail, "Accounting for Separatist Sentiment in BosniaHerzegovina and the North Caucasus of Russia: A Comparative Analysis of Survey Responses." Paper presented at the American Political Science Association annual meeting, Philadelphia, PA, September 1, 2006 [http://www.colorado.edu/ibs/waroutcomes/manuscripts.html].

O'Loughlin, John, Vladimir Kolossov and Jean Radvanyi, "The Caucasus in a Time of Conflict, Demographic Transition, and Economic Change," Eurasian Geography and Economics, 48, 2:135-156, 2007. 
Pallot, Judith, "Rural Depopulation and the Restoration of the Russian Village under Gorbachev," Soviet Studies, 42, 4:655-674, 1990.

Pallot, Judith and Dominique Moran, "Surviving the Margins in Post-Soviet Russia: Forestry Villages in Northern Perm' Oblast," Post-Soviet Geography and Economics, 41, 5:341-364, 2000.

Pavlovskaya, Marianna, "Multiple Economies of Moscow Households in the 1990s," Annals of the Association of American Geographers, 94, 2:329-351, 2004.

Radvanyi, Jean and Shakhmardan Muduyev, "Challenges Facing Mountain Peoples of the Caucasus," Eurasian Geography and Economics, 48, 2:157-177, 2007.

Rosstat (Federal'nay sluzhba gosudarstvennoy statistiki), “Vserossiyskoy perepis' naseleniya 2002 goda. 3. Naseleniye po natsional'nosti i vladeniyu Russkim yazykom po sub"yektam (All-Russian Census of Population 2002. 3. Population by Nationality and Command of the Russian Language by Federation Subjects" [http://www.perepis2002.ru/ct/doc/TOM_04_03.xls], 2003.

Rowland, Richard H., "Recent Demographic Trends in Armenia: Results of the 2001 Census and Update to 2006," Eurasian Geography and Economics, 48, 1:73-94, 2007.

Ryazantsev, Sergey V., Migratsionnaya situatsiya v Stavropol'skom kraye v novykh geopoliticheskikh usloviyakh (Migratory Situation in Stavropol' Kray under the New Geopolitical Conditions). Stavropol', Russia: Stavropol State University, Institute of Geography, 1999.

Ryazantsev, Sergey V., Sovremennyy demograficheskiy i migratsionnyy portret Severnogo Kavkaza (Contemporary Demographic and Migratory Portrait of the North Caucasus). Stavropol', Russia: Serviseshkola, pp. 78-81, 2003.

Srednik, Oleg V. and Aleksandr N. Panin, Geografiya krasnogvardeyskogo rayona; Uchebnoye posobiye (Geography of Krasnogvardeyskiy Rayon: Teaching Aid). Stavropol', Russia: Stavropol' State University Press, 2004.

TsSU (Tsentral'noye Statisticheskoye Upravleniye), Chislennost' $i$ sostav naseleniya SSSR po dannym vsesoyuznoy perepisi naseleniya $1979 \mathrm{~g}$. (Size and Composition of the Population of the USSR from Data of the 1979 All-Union Census of Population). Moscow, USSR: Finansy i statistika, 1984.

Tsvetkov, Oleg, "Ethnic Russians Flee the North Caucasus," Russian Analytical Digest, 7:9-13, 2006 [http://www.res.ethz.ch].

Vendina, Olga I., Vitaliy S. Belozerov, and Andrew Gustafson, "The Wars in Chechnya and Their Effects on Neighboring Regions," Eurasian Geography and Economics, 48, 2:178-201, 2007.

Zayonchkovskaya, Zhanna A., Migratsii: Naseleniye Rossii 1999 (Migrations: The Russian Population 1999). Moscow, Russia: Knizhniy dom Universitet, 2000, 119-156.

Zayonchkovskaya, Zhanna A., "Migratsionnaya politika Rossii, pro et contra: Problem' migratsii i opyt yeye regulirovaniya v poletnichnom Kavkazskom regione (Migration Policy of Russia, Pro and Con: Problems of Migration and Experience in Its Regulation in the Polyethnic Caucasian Region). Moscow-Stavropol', Russia: Stavropol' State University Press, 100-102, 2003. 